\title{
The Basic Study of Influence of Energy Storage Systems on Wind Power Generation Systems
}

\author{
Makoto Goto Student Member (Tohokugakuin University, makoto_1981@msn.com) \\ Guohong Wu Member (Tohokugakuin University, wugh@tjcc.tohoku-gakuin.ac.jp) \\ Yasuyuki Tada Senior Member (Tokyo Electric Power Company) \\ Tamotsu Minakawa Member (Tohokugakuin University, minakawa@tjcc.tohoku-gakuin.ac.jp)
}

Keywords: wind power generation, EDLC, power leveling, voltage fluctuation control, transient stability

Wind power, a renewable and environmentally friendly energy source, is becoming increasingly important and is now considered to be a viable source of alternative energy. In recent years, many large-scale wind farms have been incorporated into power grids. However, one of the biggest problems of wind power is that output cannot be fully controlled due to the output fluctuations of the wind caused by wind gusts. With large-scale integration of wind power into a power grid, the variation of wind power may cause some problems, e.g., voltage instability and frequency control problems, which should be resolved adequately to avoid negative effects on the existing power grid. In this work, the improving effects of power storage system such as EDLC (Electric Double Layer Capacitor) on the properties of wind power generation systems is investigated, and frequency characteristics and transient stability in these cases are verified.

Digital simulation study is conducted in this work and wind power generation system model given in Fig. 1 are used. Block diagram of control system of EDLC is shown in Fig. 2.

The following cases of wind power generation system with EDLC are studied in this work.

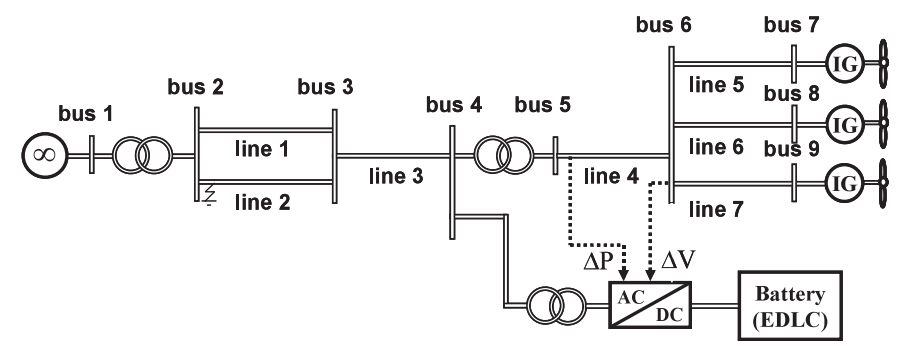

Fig. 1. Wind power generation system model

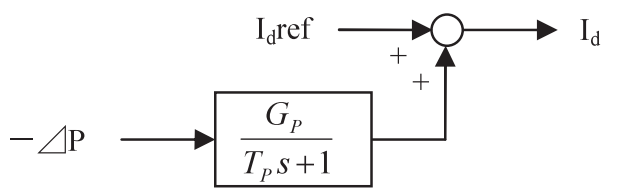

(a) Control system of d-axis current

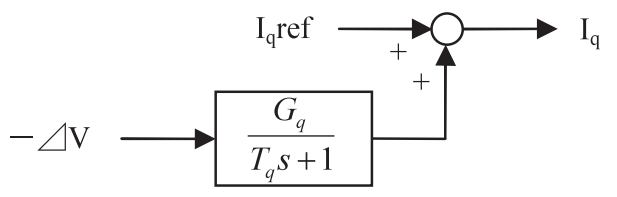

(b) Control system of q-axis current

Fig. 2. Block diagram of control systems of EDLC

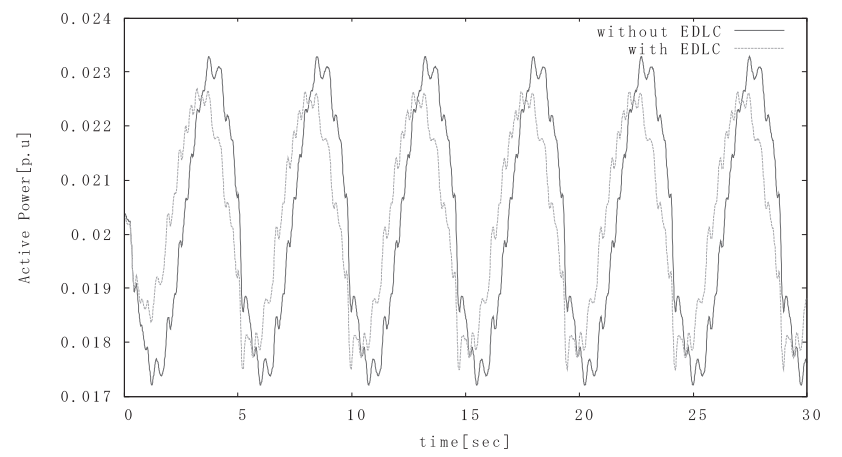

Fig. 3. Active power of transmission line 3

(1) In normal operating condition, while wind power includes sinusoid waves with various frequencies $(0.2-0.5 \mathrm{~Hz})$ and vibrates with an amplitude of 0.1 p.u., frequency characteristics of fluctuation of active power through the tie transmission line 3 and voltage deviation of bus 6 are investigated, in case of EDLC with different amounts of capacities and time constants in its control systems. The power flowing through the tie transmission line 3 in cases of power grid with and without EDLC is plotted in Fig. 3

(2) In order to confirm the transient stability of wind power generator, CCTs (Critical Clear Time) are checked, with a 3LG-O occuring in transmission line 2. And, CCTs are compared among cases with different EDLC capacities and time constants of EDLC control systems as well.

The results in this work reveal the following effects:

(1) EDLC controlled by d-aix and q-axis current regulating system can lead to not only power leveling effect but also voltage fluctuation supppressing effect.

(2) EDLC with large amount of capacity may have better effects, however, there exists an optimal value. Furthermore, while EDLC have enough capacity, a smaller time constant of EDLC control system will bring about better effects.

(3) Transient stability can be improved by introducing EDLC to a suitable location. Under the study conditions in this work, a smaller time constant of EDLC control system is found to lead to better transient stability improving effect, however, no change is observed while EDLC capacity is varied.

(4) In these study conditions, it seems that EDLC may have fewer power leveling effects on the sinusoid waves with wind frequency over $3.0 \mathrm{~Hz}$.

(5) EDLC may possibly leads to a negtive impact on power and voltage waves with some special frequency. 


\section{風力発電と電力貯蔵装置併用時における電力システムへの 導入効果に関する基礎検討}

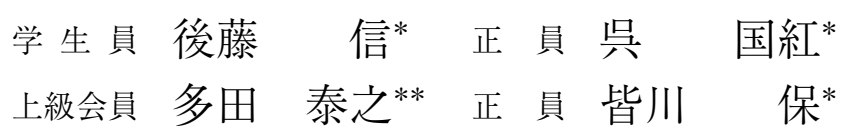

\section{The Basic Study of Influence of Energy Storage Systems on Wind Power Generation Systems}

Makoto Goto*, Student Member, Guohong Wu*, Member, Yasuyuki Tada**, Senior Member, Tamotsu Minakawa*, Member

Wind power, a renewable and environmentally friendly energy source, is becoming increasingly important and is now considered to be a viable source of alternative energy. In recent years, many large-scale wind farms have been incorporated into power grids. However, one of the biggest problems of wind power is that output cannot be fully controlled due to the output fluctuations of the wind caused by wind gusts. With large-scale integration of wind power into a power grid, the variation of wind power may cause some problems, e.g., voltage instability and frequency control problems, which should be resolved adequately to avoid negative effects on the existing power grid. In this work, the improving-effects such as power leveling and voltage fluctuation control by one of the energy storage systems-EDLC (Electric Double Layer Capacitor) on the properties of wind power generation systems is investigated, and frequency characteristics and transient stability in these cases are verified. The results illustrate the fact that a properly controlled EDLC may bring about good features to wind power generation systems.

キーワード : 風力発電, EDLC システム, 出力平準化, 電圧変動抑制, 過渡安定性

Keywords: wind power generation, EDLC, power leveling, voltage fluctuation control, transient stability

\section{1. はじめに}

近年，中国，インド，ブラジルや東南アジア諸国の急速 な工業化と経済成長は深刻なエネルギーの不足と価格の高 騰を引き起こしている。さらにエネルギー需要の一層の増 大と $\mathrm{CO}_{2}$ や公害物質の激増で, 人類の生存に深刻な危機を もたらす危険性が大きい。この危険を回避し，エネルギー 資源をめぐる国際紛争を回避するための方策を考え出すこ とが重要である(1)(2)。

COP-3 京都議定書の発効および国連による再生可能エネ ルギー開発実績管理の強化に伴い, 自然エネルギー電源と して有力な風力発電・太陽光発電等の開発を我国もこれま で以上，真剣に取組まなければならない。

このような問題に対して, 電圧変動などに関しては, 経 済産業省により制定されている系統連系技術要件ガイドラ

\footnotetext{
$*$ 東北学院大学工学部

干 985-8537 多賀城市中央一丁目 13

Tohoku Gakuin University, Faculty of Engineering

13, Chuo-Ichome, Tagajyo 985-8537

** 東京電力 (株) 技術開発研究所

干 230-8510 横浜市鶴見区江ヶ崎町 4-1

Tokyo Electric Power Company, R\&D

4-1, Egasaki-machi, Tsurumi-ku, Yokohama 280-8510
}

インによって規定されているが，周波数変動に関しては記 載されていない。この周波数・出力変動の問題に関しては 現在 NEDO プロジェクトの一環として蓄電池による変動抑 制効果が検証されている。また, 経済産業省・資源エネル ギー庁, 電力会社, 風力発電事業者の 3 者間でも, 電力貯 蔵や蓄電池の活用という具体的な対策を検討している。 本研究では, 電力貯蔵装置を風力発電近傍に導入するこ とによって, 定常時または過渡時における電力貯蔵装置の 有効性を検討することを目指している。その第一歩として 電力貯蔵装置の一つである電気二重層キャパシタ (EDLC： Electric Double Layer Capacitor) を用いてシミュレーショ ン検討を行った。またEDLC システムで有効電力のみ制御 した場合と有効電力と無効電力を同時に制御した場合の導 入効果を考察した。

\section{EDLC モデルの構築}

〈2・1〉 EDLC の等価モデル 電力貯蔵装置にはナト リウムー硫黄電池やレドックス電池, 電気二重層キャパシタ などが研究されている。この中でもサイクル寿命が長いこ と, また応答が非常に速いことなどの特徴を有する EDLC を最初の検討対象として本研究では用いる。

EDLC の等価回路は図 1 に示すように, コンデンサと抵 
抗の直列接続で構成される。図 1 の等価回路において，コ ンデンサからの直流電流 $\mathrm{I}_{\mathrm{dc}}$, 端子間の直流電圧を $\mathrm{V}_{\mathrm{dc}}$ と すると, 直流電圧と直流電流の関係は次式のように算出さ れる。

$$
V_{d c}=\frac{Q_{0}}{C}-\left(R I_{d c}+\frac{1}{C} \int I_{d c} d t\right)
$$

この各要素は以下のことを示す。

$$
Q_{0} \text { : 初期充電量, } C: \text { EDLC 容量, } R \text { : 内部抵抗 }
$$

また，本論文で使用したEDLC のパラメータを表 1 に示す。

〈2・2〉放電深度を考慮したモデルＥDLCが通常の バッテリーと異なり，完全に放電しても劣化は発生しない が，放電に伴い端子電圧が低下し，放電を持続するとチョッ パやインバータが動作できなくなるため, 本研究では, 放 電深度 (DOD : Depth of Discharge) を設定し, EDLC の直 流電圧が DODに達した場合，放電を停止させる。まだ，充 電時に関しては直流電圧が 1.0 p.u に達すると満充電になっ たと考えて，充電を停止させる。このときのフローチャー

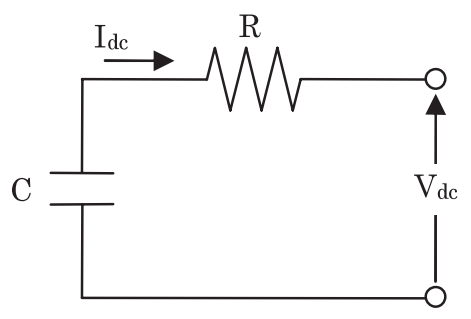

図 1 EDLC の等価回路

Fig. 1. Equivalent circuit of EDLC.

表 1 EDLC のパラメータ

Table 1. Parameter of EDLC.

\begin{tabular}{|c|c|c|c|}
\hline Capacity $\left[10^{3} \mathrm{~F}\right]$ (p.u.) & 1.0 & 10 & 100 \\
\hline Internal Resistance (p.u.) & 0.5 & 0.05 & 0.005 \\
\hline
\end{tabular}

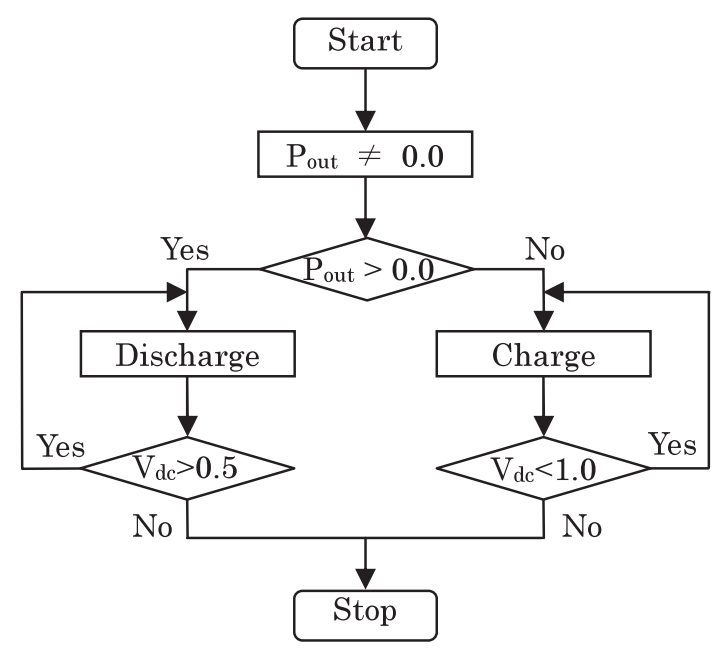

$\mathrm{V}_{\mathrm{dc}}$ : 直流電圧, $\mathrm{P}_{\text {out }}:$ EDLC 出力

図 2 放電深度を考慮した EDLC 制御

Fig. 2. EDLC control considering depth of discharge.
トを図 2 に示す。

\section{3. 系統構成とインバータ制御系}

〈3・1〉系統構成＼cjkstart系統構成を図 3 に示す。モデルは $2.5 \mathrm{MW}$ の発電機 4 台をまとめ 1 台の等価な誘導発電機に 表現している。それぞれの運用状態は以下の通りである。 系統定数を表 2 に示す。

(1) 風力発電機：容量 $10(\mathrm{MVA})$ を 3 台, 各々 $7(\mathrm{MW})$ 出 力で運転。

(2) 変圧器: 一次系統連系を想定し，154 (kV) に昇圧。

(3) 送電線: 亘長 $100(\mathrm{~km})$ 。線種は ACSR, $200\left(\mathrm{~mm}^{2}\right)$, 1 導体で, 1 回線当たりの熱的容量限界は $140(\mathrm{MW})$ 。

本研究では, MidFielder 系統解析総合環境システムを用 いてシミュレーションを行なう。EDLCの容量は 1.0 p.u. の場合が $1000 \mathrm{~F}$ (蓄電容量 $5 \mathrm{MJ}$ ) であり, 変換器の容量が 5 MVA と設定される。変換器モデルは MidFielderの中に 用意されたもの（PLL モデル，ACR モデル，変換器及び変 圧器モデルなどを含む）を使用する。

〈3・2〉 インバータ制御系ＥDLC システムは風力発 電機連系母線（bus 4) に変圧器を介して設置する。このよ うに風力発電所付近に設置することで無効電力補償制御を 同時に行い，電圧変動に関しても抑制することも可能であ

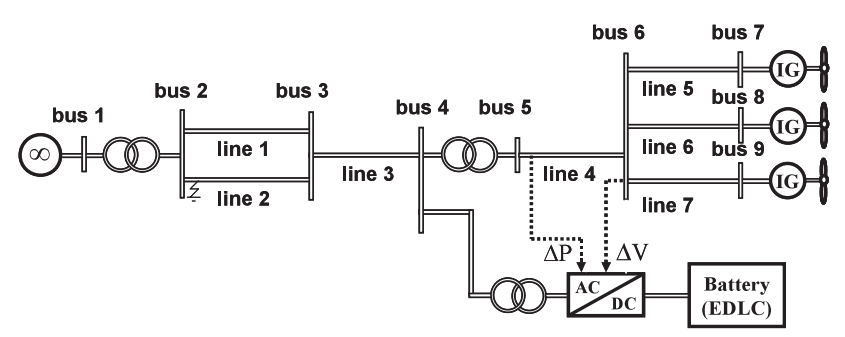

図 3 電力系統モデル

Fig. 3. Power system model.

表 2 系統定数

Table 2. Parameter of power system.

\begin{tabular}{|l|}
\hline 【System Constants】 \\
System Base 1000(MVA) \\
\hline 【Transmission System】 (1000(MVA) Base) \\
$\mathrm{Z}=0.0073+\mathrm{j} 0.01875(\mathrm{p} . \mathrm{u} / \mathrm{km})$ \\
$\mathrm{jY} / 2=0.000056(\mathrm{p} . \mathrm{u} / \mathrm{km})$ \\
\hline 【Transformer】 \\
Rated output $=30.0(\mathrm{MVA})$ \\
$\mathrm{X}=0.11(\mathrm{p} . \mathrm{u})$ \\
\hline 【Induction Generator Constants $】$ \\
Pole Number $: 4$ pole \\
Stator resistance $: 0.01(\mathrm{p} . \mathrm{u})$ \\
Stator leakage reactance $: 0.15(\mathrm{p} . \mathrm{u})$ \\
Rotor resistance $: 0.005(\mathrm{p} . \mathrm{u})$ \\
Rotor leakage reactance $: 0.15(\mathrm{p} . \mathrm{u})$ \\
Excitation reactance $: 3.0(\mathrm{p} . \mathrm{u})$ \\
Inertia : $2.0(\mathrm{sec})$ \\
\hline
\end{tabular}




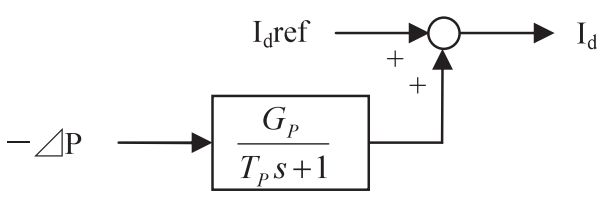

(a) Control system of direct axis current

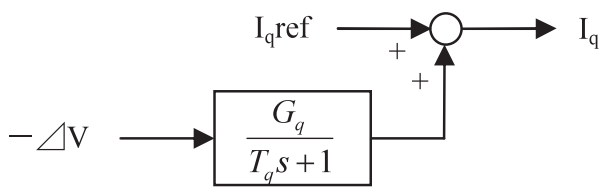

(b) Control system of quadrature axis current

図 4 インバー夕制御系

Fig. 4. Block diagram of control systems of EDLC.

ると考えられる。インバータの制御系は図 4 に示すような 単純な一次遅れ要素とした。

インバータでは $\mathrm{d}$ 軸上の電流成分 $\left(\mathrm{I}_{\mathrm{d}}\right)$ と $\mathrm{q}$ 軸上の電流 成分 $\left(\mathrm{I}_{\mathrm{q}}\right)$ を独立に制御している。電圧が平衡していれば, 有効電力は $\mathrm{I}_{\mathrm{d}}$ に比例し，無効電力は $\mathrm{I}_{\mathrm{q}}$ に比例する。その ため $\mathrm{I}_{\mathrm{d}}$ 制御系に line 4 の有効電力偏差の逆位相を入力し, $\mathrm{I}_{\mathrm{q}}$ 制御系には bus 6 の電圧偏差の逆位相を入力する。

\section{4. 風況変動時の EDLC システム導入効果}

〈4・1 EDLC システム導入効果と制御系の影響 風 力発電の出力には様ざまな周波数成分が含まれているが, 検 討のため，まず風況の変動を周波数 $0.2 \mathrm{~Hz}$ ，大きさ $0.1 \mathrm{p} . \mathrm{u}$ の正弦波状に変動させる条件として考察した。この場合の 風力発電機の有効電力出力 (実効值) 変動の様子を図 5 に示 す（系統から電力を吸収する方向を正とする），図５から風 力発電機の過渡特性により風力発電機の出力に細かい振動 が発生することがわかる。また EDLCでは，容量を 10 p.u. $\left(10 \times 10^{3} \mathrm{~F}\right)$, インバータの制御時定数を $\mathrm{T}_{\mathrm{p}}=\mathrm{T}_{\mathrm{q}}=1.0 \mathrm{sec}$ と設定した。

（1）有効電力補償制御 インバー夕制御ゲインを $\mathrm{Gp}=95, \mathrm{Gq}=0$ と設定したときの連系線 line 3 の潮 流を図 6, 風力発電機接続母線 bus 6 の電圧を図 7 に示す。 そのときの EDLC の有効電力出力, 直流電圧と直流電流の 波形を図 8〜図 10 に示す。図 6 と図 7 から, EDLC システ ムを導入することにより出力変動を抑制していることが確 認できる。しかしながら，電圧変動に関してはほとんど影 響がないことも見られる。また, 風力発電機の出力に含まれ る細かい振動はEDLC の出力で補償できず連系線 line 3 の 潮流にも現れた。これは，今回の検討で用いられる EDLC の制御系また変換器の応答がこれらの速い振動に追従でき ないからと考えられる。

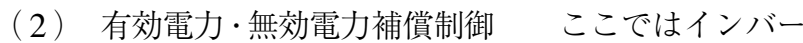
夕制御ゲインを $\mathrm{Gp}=95, \mathrm{Gq}=30$ と設定することで，電 圧変動抑制効果を検討した。そのとき line 3 における線路 潮流と bus 6 の電圧を図 11，図 12 に示す。無効電力を同 時に制御した場合，出力に関しては図 6 と大差はないこと

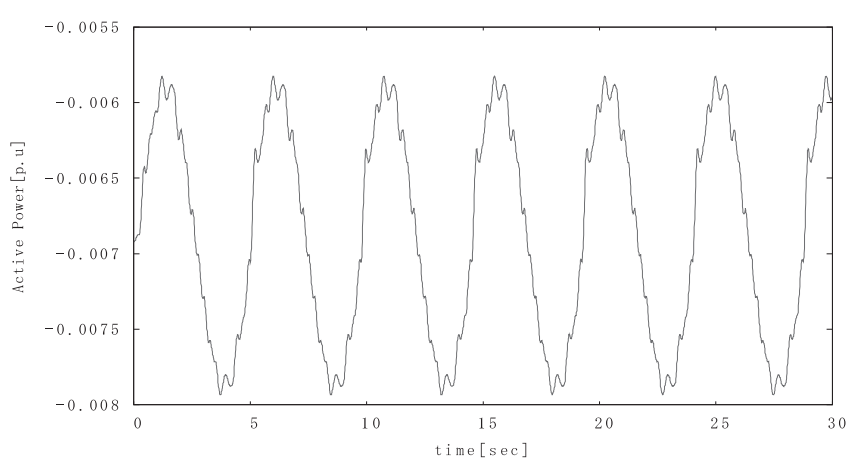

図 5 風力発電機の有効電力出力

Fig. 5. Active power from wind power generator.

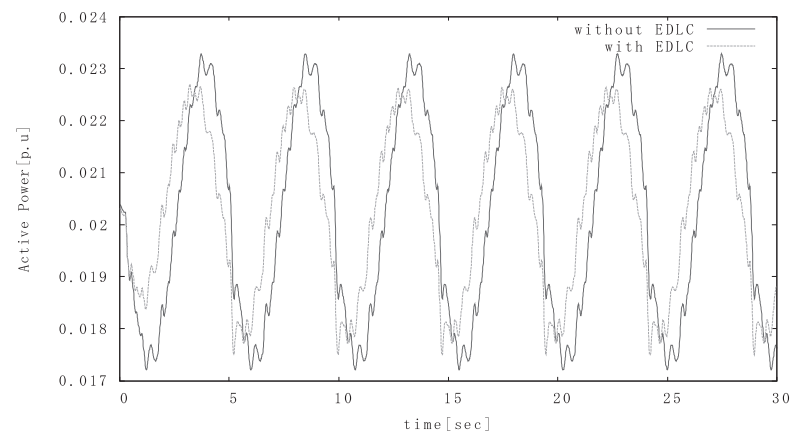

図 6 有効電力のみ制御したときの連系線 line 3 の潮流

Fig. 6. Power flow of line 3 with P control.

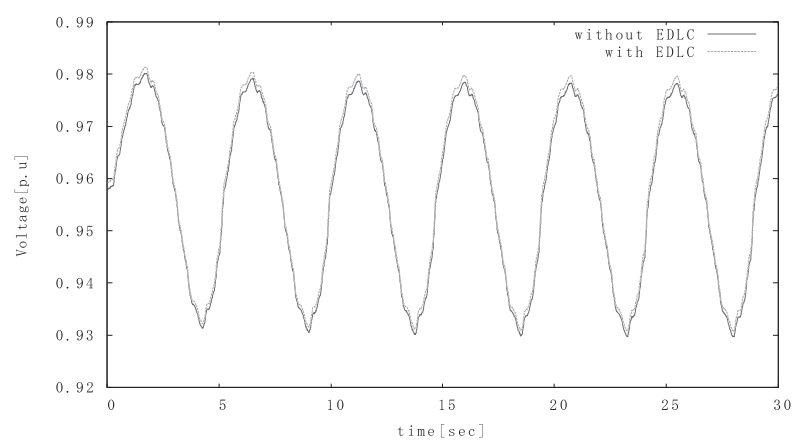

図 7 有効電力のみ制御したときの母線 bus 6 の電圧

Fig. 7. Voltage of bus 6 with $\mathrm{P}$ control.

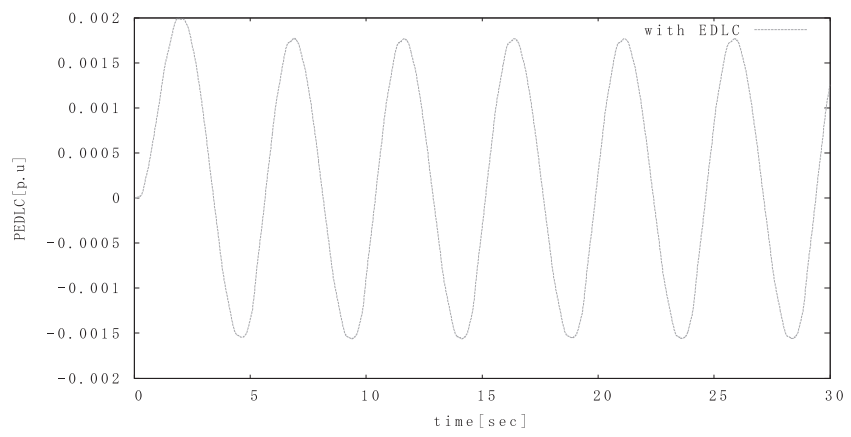

図 8 有効電力のみ制御したときの EDLC の 有効電力出力

Fig. 8. Active power of EDLC with P control. 


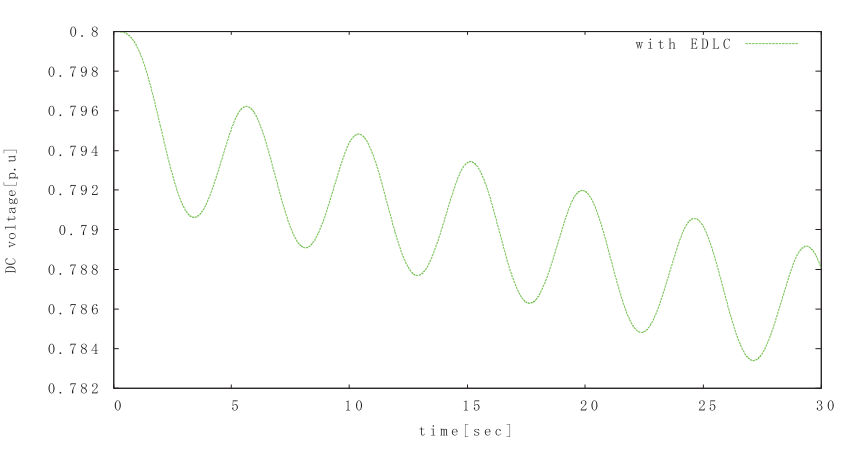

図 9 有効電力のみ制御したときの EDLC の直流電圧

Fig. 9. DC voltage of EDLC with P control.

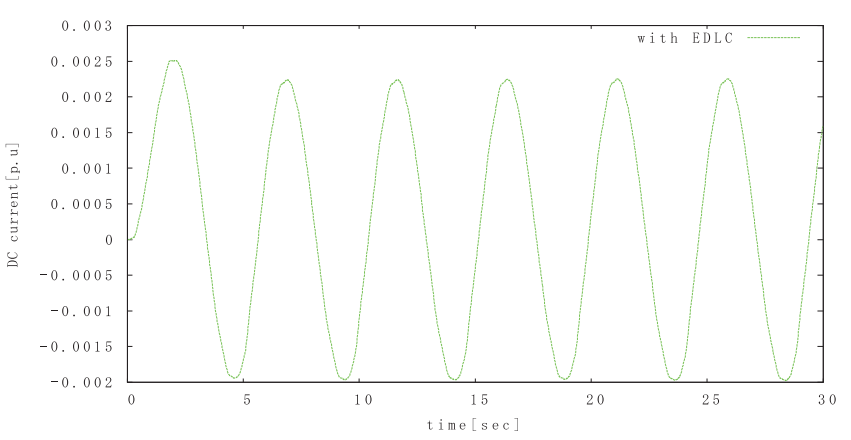

図 10 有効電力のみ制御したときの EDLC の直流電流 Fig. 10. DC current of EDLC with P control.

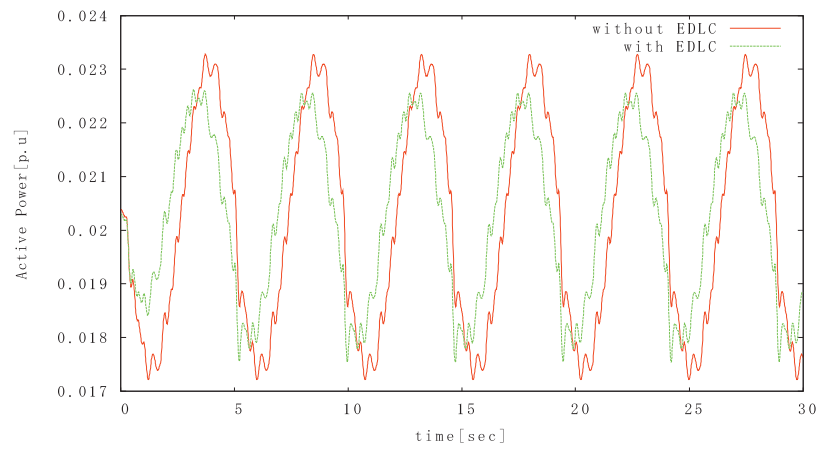

図 11 有効 - 無効電力同時制御時の連系線 line 3 の潮流

Fig. 11. Power flow of line 3 with P \& Q control.

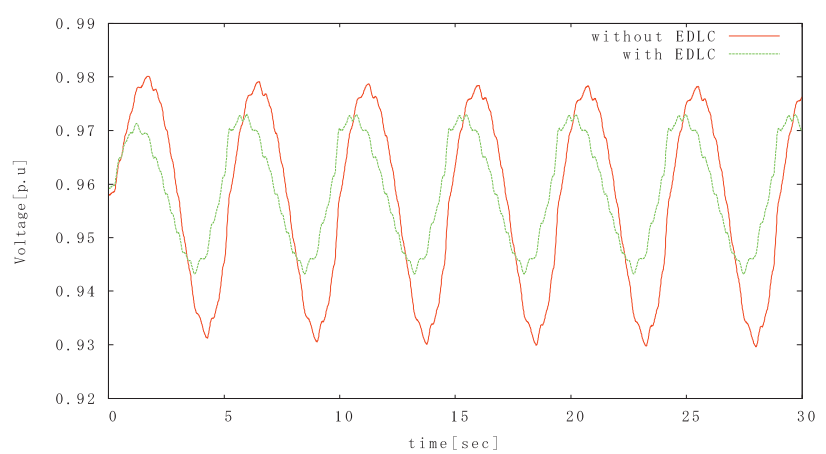

図 12 有効・無効電力同時制御時の母線 bus 6 の電圧

Fig. 12. Voltage of bus 6 with P \& Q control.
が確認できる。しかしながら，図 12 の母線 bus 6 の電圧波 形を見ると, 図 7 に比べ電圧変動がかなり良く抑制されて いることは確認できる。

〈4・2〉 EDLC システムの整定定数に関する一考察

EDLC 導入により出力・電圧変動抑制効果を向上するた めの EDLC システムの整定定数について概略検討を行う。

（1）EDLC 容量に関する一考察 インバータの制御 時定数を $0.5 \mathrm{sec}$ と設定し, EDLC 容量を 1，10，100 p.u. と変化させた場合の変動抑制効果について検討を行う。ま た，放電深度を $50 \%$ とし，EDLCには予め $80 \%$ 充電されて いるものとする。このときの連系線 line 3 の潮流を図 13 ,

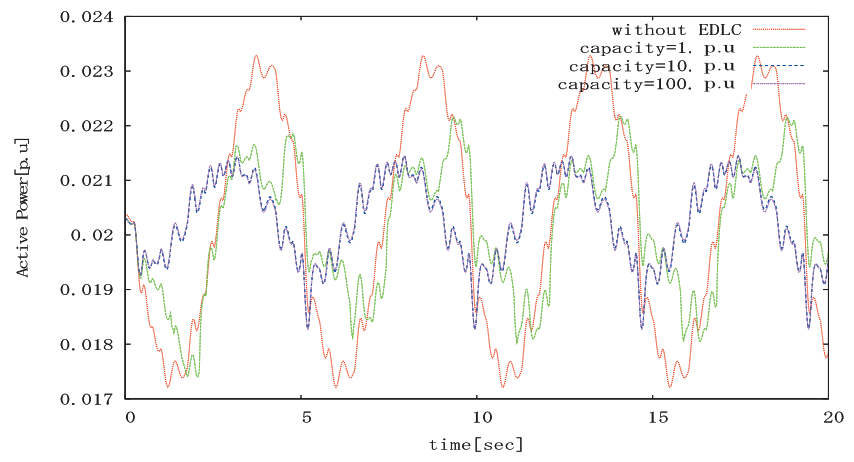

図 13 EDLC 容量と連系線 line 3 の潮流変動抑制効果

Fig. 13. Power leveling effect on line 3 in cases of different EDLC capacity.

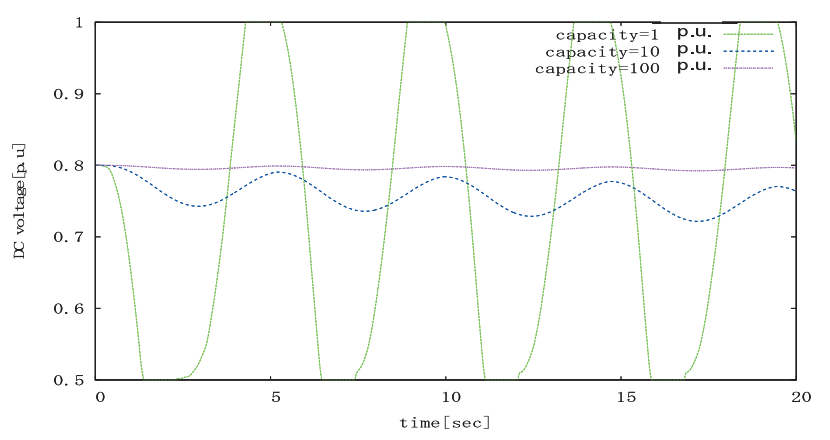

図 14 EDLC 容量と直流電圧

Fig. 14. DC voltage in cases of different EDLC capacity.

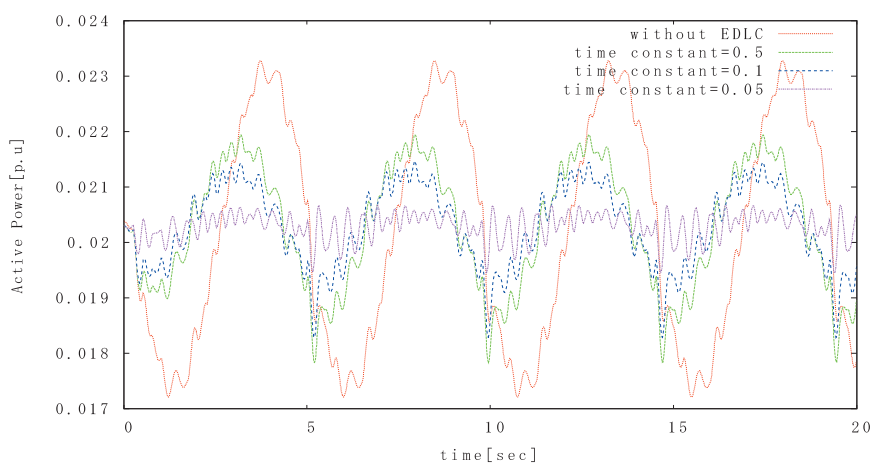

図 15 制御時定数と連系線 line 3 の潮流变動抑制効果

Fig. 15. Power leveling effect on line 3 in cases of different time constant with EDLC control system. 
EDLC の直流電圧を図 14 に示す。図 13, 図 14 に示すよ うに, EDLC の容量が小さい場合, 直流電圧が放電深度や 満充電に達するため繰り返し動作し, 出力補償効果が良く ないことがわかる。しかしながら，容量の大きな EDLCを 設置すればよいというわけではない。図 13 により，容量が 10 と 100 p.u. の場合では出力変動に大差を見出すことがで きない。これより, EDLCの設置容量には最適值が存在し ていることがわかる。本研究では，EDLCの妥当な容量は 10 p.u. と考えている。電圧変動に関しても同様な結果は確 認できた。

（2）インバータ制御時定数に関する一考察ＥDLC の容量を 10 p.u. 一定とし，インバータ制御時定数を 0.5 , $0.1,0.05 \mathrm{sec}$ と変化させたときの line 3 の線路潮流を図 15 に示す。図 15 によりEDLCの制御時定数を小さく設定す ることで変動抑制効果が非常に高くなることが分かる。こ のことより変動抑制効果に関しては, EDLCが風力発電機 の出力変動を吸収するのに十分な容量である場合には，イ ンバータの動作速度を速めるほうが効果的であることがわ かる。電圧変動に関しても同様にインバータの制御時定数 が小さいほど変動抑制効果は向上することが確認できた。

〈4·3〉様ざまな風況周波数に対する EDLC システム導 入効果の評価今までの検討では風況の変動を周波数 $0.2 \mathrm{~Hz}$ ，大きさ $0.1 \mathrm{p} . \mathrm{u}$ の正弦波としたが，風力発電の出力 変動には様ざまな周波数成分が含まれているため，ここでは 風況の変動を大きさ一定 (0.1 p.u) の正弦波とし, 周波数を $0.2 \sim 5.0 \mathrm{~Hz}$ に変動させた場合において検討を行い, どのよ うな変動周波数の成分を抑制可能であるかを考察する。ま た, 有効電力のみ制御した場合 $(\mathrm{Gp}=95, \mathrm{Gq}=0)$ と, 有効 電力と無効電力を同時に制御した場合 $(\mathrm{Gp}=95, \mathrm{Gq}=30)$ について比較する。

（1）有効電力制御のみ EDLC の容量を 10 p.u., イ ンバータの制御時定数を $0.5 \mathrm{sec}$ と設定したとき，それぞ れの变動周波数に対する出力变動補償効果をまとめた結果 を図 16 に示す。このように風況の変動周波数に一定の割 合で影響を受けるのではないことが確認できる。また，こ の出力変動のピークは $2.2 \mathrm{~Hz}$ 付近である。このときの系 統固有值を計算すると, $-2.06+\mathrm{j} 14.58$ の固有值が存在す ることがわかる。このモードの周波数は約 $2.3 \mathrm{~Hz}$ であり, 眓 16 の出力変動のピーク值とほぼ一致した。そこで, この 場合の EDLC システムの周波数応答 $\Delta \mathrm{V}_{4}(\mathrm{j} \omega) / \Delta \mathrm{P}_{\mathrm{EDLC}}(\mathrm{j} \omega)$ を計算してその結果を図 17 に示す。系統の固有周波数（約 $2.3 \mathrm{~Hz})$ において, 図 17 に示すようにEDLC システムの マグニチュードは -130 から -20 に大きくなっている。こ れより, 今回の検討では, EDLC システムの周波数応答ゲ インのピークとモデル系統の固有值モードがほぼ一致する 条件であったため, EDLCの応答と電力ネットワークに存 在する固有モードと相互作用を引き起こして，EDLCを導 入することによりこの周波数付近で変動が大きくなったと 考えられる。この結果により，EDLC システムの制御系の 設計に当たっては, 適用系統の固有周波数を考慮に入れる

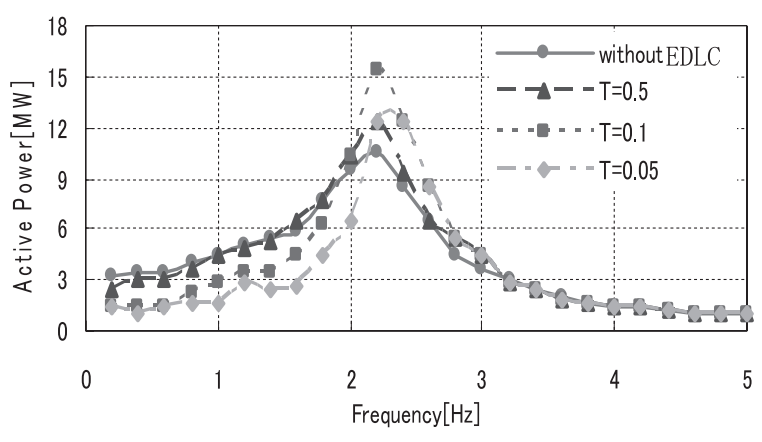

図 16 風況の周波数による連系線 line 3 の潮流変動 Fig. 16. Response of active power through transmission line 3 to frequency of wind.

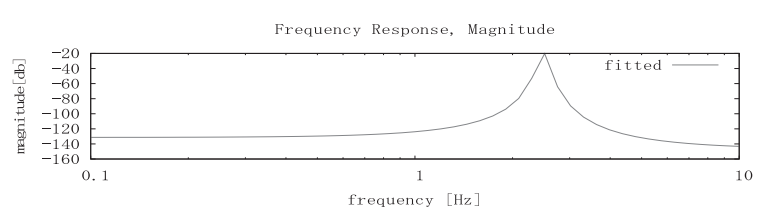

Frequency Response, Phase Ang1e

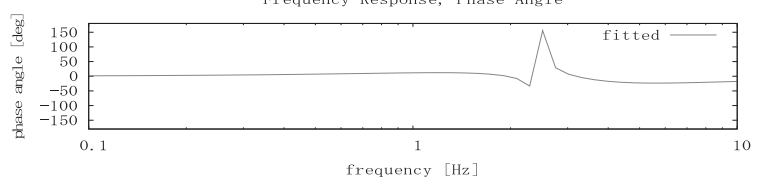

図 17 EDLC システムの周波数応答計算結果

Fig. 17. Frequency response of EDLC system.

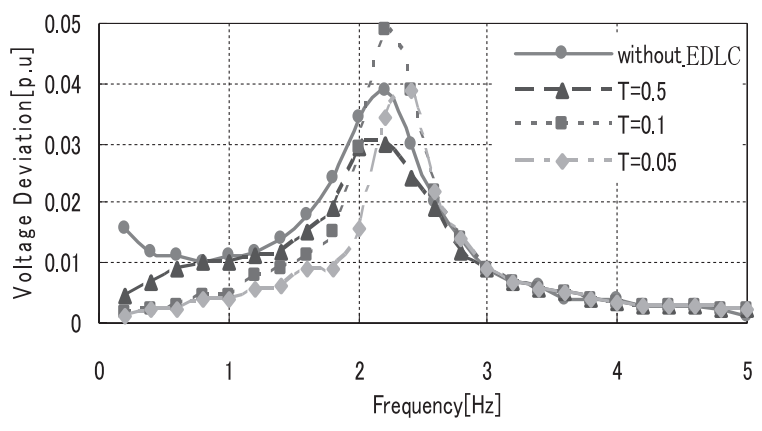

図 18 風況の周波数による母線 bus 6 の電圧変動

Fig. 18. Voltage response of bus 6 to frequency of wind.

必要があると思われる。

また，図 16 から制御時定数を小さく設定することで出 力変動が非常に小さくなっていることが確認できる。しか しながら, 変動周波数が $3.0 \mathrm{~Hz}$ 以上になると EDLC の制 御系やインバータの応答などは風力発電機の出力変動を追 従できなくなり, 出力変動抑制効果を見出すことができな かった。また, 上述と同様な理由で, 電力ネットワークと の相互作用を引き起こしている $2.2 \mathrm{~Hz}$ 付近で出力変動が大 きくなっていることが考察できる。

（2）有効電力と無効電力制御 EDLC の容量を 10 p.u. 一定とし, 有効電力と無効電力を同時に制御した 場合のインバータ制御時定数による設置母線電圧の変動抑 制効果を図 18 に示す。困 18 のように, $2.0 \mathrm{~Hz}$ 以下の変動 
成分に対して，時定数を小さく設定することで変動抑制効 果を向上することが確認できる。ただし， $1.0 \mathrm{~Hz}$ 以下に関 しては時定数 $0.1 \mathrm{sec}$ と $0.05 \mathrm{sec}$ の場合では大差を見出すこ とができない。これより，時定数を小さく設定することで いくらでも変動を抑制できるわけではないことがわかる。 また，この場合も $3.0 \mathrm{~Hz}$ 以上の変動成分を抑制する効果は 見られず， $2.2 \mathrm{~Hz}$ 付近で変動が大きくなる場合もある。

\section{EDLC 導入時の風力発電機の過渡安定性}

〈5・1〉 故障条件故障条件は初期状態として 1 回線 の三相地絡事故に対して主保護遮断 5 サイクル $(0.1 \mathrm{sec})$ で 故障回線が両端で除去する。また故障点は図 3 に示すよう

に line 2 の無限大母線高圧側出口至近端とした。

ここでは風力発電機の過渡安定性を定量的に検討するた め故障臨界故障除去時間（CCT：Critical Clear Time）を使 用し，評価を行った。初期状態において CCT は $94 \mathrm{~ms}$ と なる。

このときEDLC システムを導入しなければ，地絡故障が 発生することにより接続点の電圧が低下し, 風力発電機の 安定運転が阻害されて，適当な時間で故障が除去されない と風力発電機が停止してしまう。そこで, EDLC システム を導入することにより，接続母線 bus 6 の電圧を維持する 検討を行う。

\section{〈5・2〉 EDLC システム導入時の風力発電機の安定性}

初期状態において，風力発電機を安定に運転するために は風力発電機接続母線の電圧を維持する必要がある。Id 制 御のみ $(\mathrm{Gp}=95, \mathrm{Gq}=0)$ の場合には図 7 に示したよう に風力発電機接続母線の電圧変動を抑制することができな いため，風力発電機の過渡安定性を確保できないと考えら れる。そこで，Id，Iq を独立に制御（ $\mathrm{Gp}=95 ， \mathrm{Gq}=30)$ を行い，無効電力を制御することで風力発電機接続母線の 電圧を維持することが可能と考えられるため，本項では Id と Iq を同時に制御した場合について検討を行う。

まず，EDLC の容量を 10 p.u. と設定し，インバータ制 御時定数を $1.0,0.5,0.2(\mathrm{sec})$ と変化させた場合を検討す る。このときの連系線 line 3 の潮流と風力発電機接続母線 bus 6 の電圧をそれぞれ図 19 と図 20 に示す。これらの図 により，EDLCを導入し無効電力を同時に制御することで， 事故後に風力発電機は安定に運転することができ，過渡安 定性を向上することがわかる。また，インバー夕制御時定 数を小さくすることによって，事故回復後の電圧の立ち上 がりが非常に速くなり，これにより CCTも向上できたこ とがわかる。

次に, EDLCの容量の影響について考察する。EDLCの インバー夕制御時定数を $0.5 \mathrm{sec} に$ 固定し，容量を変化させ たときの風力発電機接続母線 bus 6 の電圧を図 21 に示す。 図 21 により, 小容量 (1.0 p.u.) の EDLC を導入しても過 渡安定性向上効果が得られることがわかる。また，今回検 討した条件では，容量を大きく設定しても母線電圧に変化 を見出すことができなかった。これは今回の故障条件にお

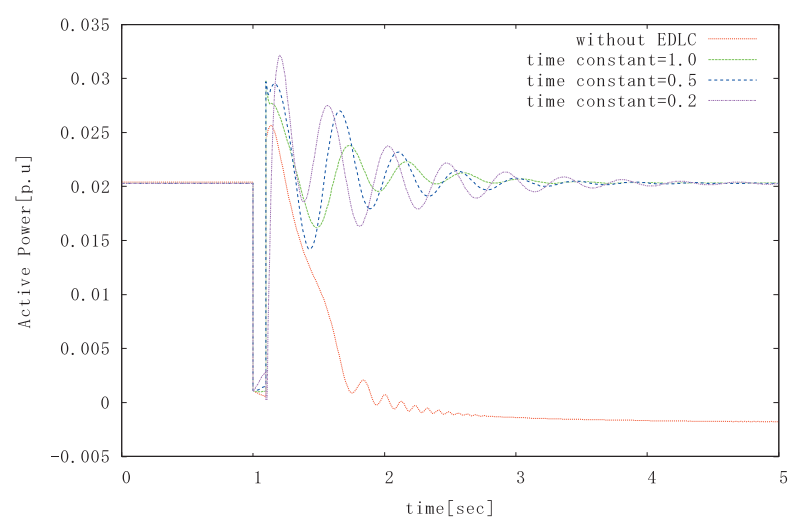

図 19 インバー夕制御時定数変化時の連系線 line 3 の潮流

Fig. 19. Active power of line 3 in cases of different time constant with EDLC control system.

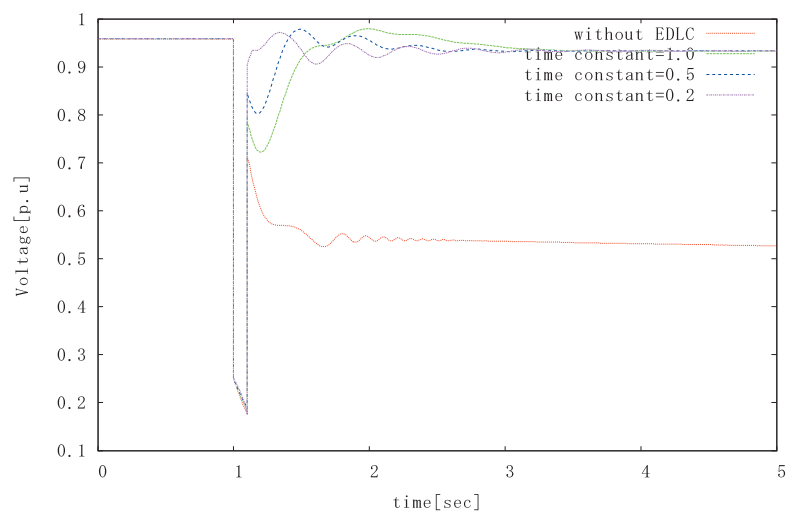

図 20 インバー夕制御時定数変化時の 母線 bus 6 の電圧

Fig. 20. Voltage of bus 6 in cases of different time constant with EDLC control system.

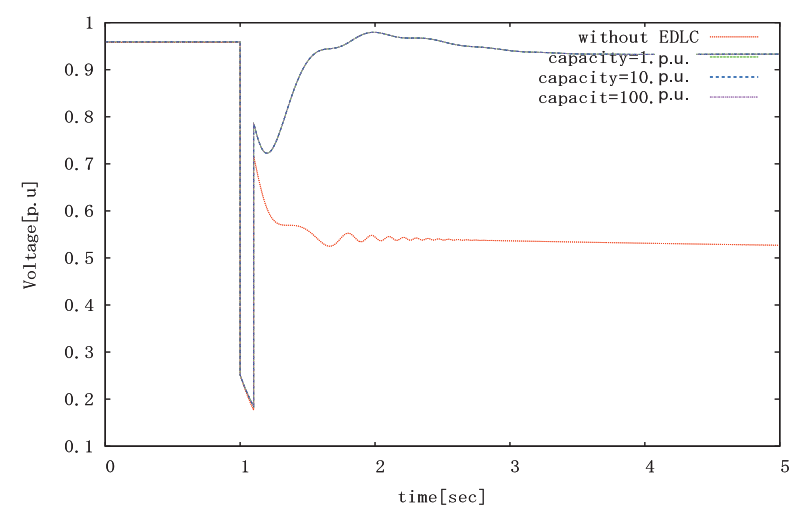

図 21 EDLC 容量変化時の母線 bus 6 の電圧

Fig. 21. Voltage of bus 6 in cases of different EDLC capacity.

いては，用いられた最小容量（1.0p.u.）でも出力変動を吸 収するのは十分な容量であるからと考えられる。

EDLC の容量とインバータ制御時定数が変化した場合の CCT の結果を表 3 にまとめる。

表 3 より, 今回のシミュレーション検討条件においては, 
表 3 EDLC システム導入時における CCT の関係

Table 3. Relationship between CCT and EDLC capacity \& time constant of EDLC control system.

\begin{tabular}{|c|c|c|c|}
\hline $\begin{array}{r}\text { Time Const. } \\
\text { Capacity(p.u.) }\end{array}$ & $\begin{array}{c}1.0 \\
(\mathrm{sec})\end{array}$ & $\begin{array}{c}0.5 \\
(\mathrm{sec})\end{array}$ & $\begin{array}{c}0.2 \\
(\mathrm{sec})\end{array}$ \\
\hline 1 & $120(\mathrm{~ms})$ & $136(\mathrm{~ms})$ & $148(\mathrm{~ms})$ \\
\hline 10 & $120(\mathrm{~ms})$ & $136(\mathrm{~ms})$ & $148(\mathrm{~ms})$ \\
\hline 100 & $120(\mathrm{~ms})$ & $136(\mathrm{~ms})$ & $148(\mathrm{~ms})$ \\
\hline
\end{tabular}

EDLC のインバータ制御時定数を小さく設定すると過渡安 定度を向上できること，またEDLC の容量を変化させても CCT に大きく影響を与えないことがかわる。

\section{6. まとめ}

本論文では EDLC システムを導入し, 風力発電による連 系線潮流 ·風力発電機の接続母線電圧変動の抑制効果と系 統事故時の風力発電機の安定性について検討を行った。そ の結果を以下にまとめる。

（1）EDLC の電力変動抑制制御によって連系線潮流の 平準化効果が得られ，無効電力を同時に制御することによ り電圧変動も抑制可能である。

（2）EDLC が風力発電機の出力変動を吸収するのは十 分な容量である場合には，制御時定数を小さく設定するこ とが変動抑制効果の向上に効果的である。

（3）EDLC 導入により風力発電機の過渡安定性が向上 できる。今回検討した条件では，制御時定数を小さく設定 することにより更に過渡安定性を向上できるが，EDLCの 容量を変化させた場合は影響が見られなかった。

（4）今回検討した条件では, 風況の変動周波数が $3.0 \mathrm{~Hz}$ 以上になるとEDLCによる変動抑制効果が見られなかった。 このことにより, EDLCの制御系や応答特性などの影響で, 抑制できる变動周波数には限界があると思われる。

（5） EDLC システムの制御系と系統の固有周波数が一 致する場合には出力・電圧変動に悪影響を及ぼす可能性が あるため，適用系統の固有周波数を考慮に入れて制御系の 設計を行う必要がある。

今後の課題として，様ざまな電力貯蔵装置を用いた検討 として, EDLCのほかに NaS 電池やレドックスフロー電池 等の導入効果や, 風力発電に電力貯蔵装置を導入する際の 最適なバッテリー容量の検討などが上げられる。

なお，本研究では，株式会社テプコシステムズが開発し た系統解析総合環境システム MidFielderをベースにし，必 要なモデルを開発して検討を行った。

(平成 18 年 3 月 27 日受付, 平成 18 年 10 月 4 日再受付)

\section{文献}

(1) Japan Society for the Promotion of Science Research for the Future Program: Highly Efficient Use of Energy and Reduction of its Environmental Impact (2002-1)
(2) Japan Society for the Promotion of Science Research for the Future Program: $2^{\text {nd }}$ International Symposium Report of on Synthesis of Ecological High Quality Transportation Fuel (2002-1)

(3) J. Sveca and L. Söder: "Wind Power Integration in Power Systems with Bottleneck Problems", 2003 IEEE Bologna Power Tech., IEEE Catalog 07803-7967-5/03/, Italy (2003-10)

(4) O. Sakamoto and T. Nitta: "Basic Consideration on effects of Superconducting Generator on Mitigation of Voltage fluctuation in power Systems with Wind power generation", 2005 National Convention Record IEE Japan, No.6-081 (2005-3) (in Japanese)

坂本織江・仁田旦三：「風力発電導入時の超電導発電機の電圧変動 抑制効果に関する基礎検討」, 平成 17 年電気学会全国大会, No.6-081 (2005-3)

(5) T. Ishida, A. Nakamaru, Y. Shirai, T. Nitta, and K. Shibata: "Study on Online monitoring of eigen-frequency of Power-system by use of Superconducting Magnetic energy Storage", 2005 National Convention Record IEE Japan, No.5-026 (2005-3) (in Japanese)

石田智信 $\cdot$ 白井康之 $\cdot$ 中丸成人 ·仁田旦三 · 柴田勝彦：「SMES を用 いた電力系統のオンラインでの固有周波数の追従」, 平成 17 年電気 学会全国大会, No.5-026 (2005-3)

(6) H. Chikaraishi, T. Mito, F. Kawagoe, M. Iwakuma, K. Okumura, R. Abe, and K. Hayashi: "Development of SMES designed to protect from momentary voltage drop", 2005 National Convention Record IEE Japan, No.5-027 (2005-3) (in Japanese)

力石浩孝 · 三戸利行 ·住吉文夫 · 川越明史 · 岩熊成卓 - 奥村嘉賀男 · 阿部 亮・林 一夫：「瞬時電圧低下対策 SMES の開発」, 平成 17 年 電気学会全国大会, No.5-027 (2005-3)

(7) http://www.ihi.co.jp/ihi/ihitopics/topics/2005/0414-1.html

(8) H. Sugimoto, Y. Hondou, Y. Akita, T. Nishikawa, T. Tsuda, T. Takeda, T. Okazaki, S. Ohashi, and S. Yoshida: "Manufacture of High Temperature Superconducting motor", 2005 National Convention Record IEE Japan, No.5005 (2005-3) (in Japanese)

杉本英彦 ·本堂義記 · 秋田義文 ·西川友啓 - 津田鉄平 · 竹田敏雄 · 岡崎 徹 · 大橋紳悟 $\cdot$ 吉田 茂:「高温超電導電動機の試作」, 平成 17 年電気学会全国大会, No.5-005 (2005-3)

(9) G. Wu, M. Goto, T. Minakawa, and Y. Tada: "Technological Assessment for Developing New Wind Power Generation Systems", 2005 IEEE Power Tech., No.252, St. Petersburg, Russia (2005-6)

(10) M. Goto, T. Minakawa, and Y. Tada: "Assessment on Development of New Wind Power Generation Systems", 2005 National Convention Record IEE Japan, No.6-082 (2005-3) (in Japanese)

後藤 信・皆川 保・多田泰之：「新型風力発電システムに関する 事前評価（No.1）」, 平成 17 年電気学会全国大会, No.6-082 (2005-3)

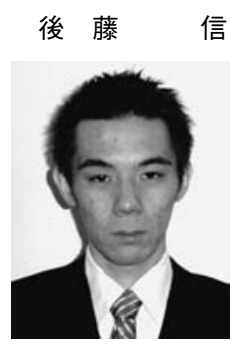

（学生員） 1981 年 12 月 30 日生。 2004 年 3 月東 北学院大学工学部電気工学科卒業。2004 年 4 月 東北学院大学大学院工学研究科博士課程前期に進 学, 現在に至る。主に電力系統安定度および新型 風力発電システムに関する研究に従事。

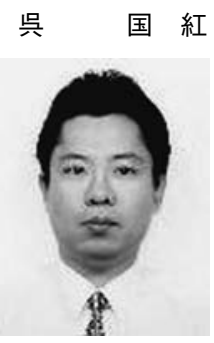

（正員） 1969 年 9 月 26 日生まれ。1989 年 9 月天 津大学電気工学科 (中国) 卒業 (B.S.)。1994 年同 大学大学院修士課程修了 (M.S.)。1997 年東京大 学および天津大学共同連繋協定に基づき大学院博 士課程修了 (Ph.D.)。1998 年 4 月〜 2001 年 3 月 東京大学大学院で JSPS 助手と協力研究員。2001 年 4 月 2005 年 3 月東北大学工学部寄附講座教 員。2005 年 4 月より東北学院大学工学部電気情報 工学科講師, 2006 年 4 月より同大学助教授。電力系統安定度, FACTS および超電導応用, HVDC, 新エネルギーシステム等研究に従事。工 学博士。IEEE 会員。 
多田 泰 之（上級会員） 1963 年 3 月 20 日生まれ。1981 年 3 月川越工業高校卒業。同年 4 月東京電力（株）入 社。1 1988 年東電学園大学部卒業後, 1989 年 4 月よ り技術開発研究所系統技術グループ勤務。1989 1990 年東京大学客員研究員。電力系統解析, 特に 統合解析システムの開発研究に従事。東京大学博 士 (工学)。1996 年電気学会論文賞, 1998 年同優 秀論文発表賞受賞。IEEE 会員。
皆川

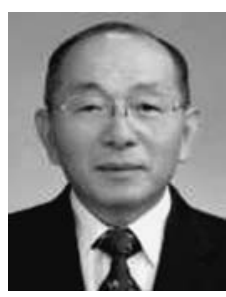

保 （正員） 1959 年 3 月早稲田大学第一理工学部電気 工学科卒業。同年 4 月東北電力 (株) 入社。発変 電, 系統計画・運用, 研究等の部門に従事。1968～ 1969 年米国 GE 社の PSEC に派遣され，系統運 用自動化・系統計画手法の調查開発研究に従事。 1994 年 7 月東北コンピュータサービス（株）出 向。1 995 年 4 月東北学院大学非常勤講師を兼務, 1997 年 4 月東北学院大学教授。京都大学博士 (工 学)。石川賞, オーム技術賞, 電気学会進歩賞等を受賞。IEEE, CIGRE 会員。 